\title{
INTERAKSI SISTEM PERTANAMAN HIDROPONIK DENGAN PEMBERIAN NUTRISI AB MIX TERHADAP PERTUMBUHAN DAN PRODUKSI SAWI
}

(Brassica juncea $\mathrm{L}$ )

\section{Qorry Hilmiyah Harahap ${ }^{1}$, Taufik Hidayat}

Email: qorryhrp@gmail.com

\begin{abstract}
${ }^{1}$ Staf Pengajar Fakultas Pertanian Universitas Muhammadiyah Tapanui Selatan Jl Raja Inal Siregar - Tanggal No 32, Padangsidimpuan 22716
\end{abstract}

\begin{abstract}
ABSTRAK
Penelitian ini bertujuan adalah untuk mengetahui pengaruh perbandingan sistem pertanaman dan mengetahui pengaruh media tanam terhadap pertumbuhan dan produksi tanaman sawi (Brassica Juncea L) dengan sistem Hidroponik. Rancangan yang digunakan adalah Rancangan Acak Lengkap (RAL) yang disusun secara faktorial dengan menggunakan 2 faktor, yaitu perlakuan nutrisi (P) terdiri dari 3 taraf yang diteliti yaitu : P0 $=$ Kontrol, P1 = Nutrisi AB Mix, P2 = Urea. Perlakuan media tanam (M) dengan 3 taraf yang diteliti yaitu : M1 = Rockwool, M2 = Serbuk Kayu, M3 = Sekam Padi. Hasil analisis secara statistik menunjukkan bahwa perlakuan nutrisi AB Mix memberikan pengaruh yang nyata pada parameter pengamatan tinggi tanaman, luas daun, warna daun, jumlah daun, berat per sampel dan berat per plot pada umur 1 minggu setelah tanam sampai dengan 4 minggu setelah tanam. Hasil tertinggi berat sawi per plot dijumpai pada perlakuan P1 yaitu Nutrisi AB Mix sebanyak 185,56 gram. Hasil analisis secara statistik menunjukkan bahwa perlakuan media tanam rockwool memberikan pengaruh nyata pada parameter pengamatan tinggi tanaman, luas daun, warna daun, jumlah daun, berat per sampel dan berat per plot pada umur 2 minggu setelah tanam sampai 4 minggu setelah tanam. Hasil tertinggi jumlah daun pada perlakuan M1 yaitu media tanam rockwool sebanyak 11.70 helai daun. Berdasarkan hasil analisis statistik interaksi dari kedua perlakuan jenis nutrisi P1 (Nutrisi AB Mix) dan media tanam M1 (Rockwool) menunjukkan pengaruh nyata pada semua pengamatan yaitu tinggi tanaman, luas daun, warna daun, jumlah daun, berat per sampel dan berat per plot.
\end{abstract}

Kata kunci: Rockwool, serbuk kayu, sekam padi, media tanam, daun

\section{PENDAHULUAN}

Sawi hijau sebagai bahan makanan sayuran mengandung zat-zat gizi yang cukup lengkap sehingga apabila dikonsumsi sangat baik untuk mempertahankan kesehatan tubuh. Sebagai sayuran, caisim atau dikenal dengan sawi hijau mengandung berbagai khasiat bagi kesehatan. Kandungan yang terdapat pada caisim adalah protein, lemak, karbohidrat, Ca, P, Fe, Vitamin A, Vitamin B, dan Vitamin C. Kondisi saat ini produksi sawi di Sumatera Utara mengalami penurunan selama kurun waktu
5 tahun terakhir. Sebagimana yang dinyatakan oleh Badan Pusat Statistik Sumatera Utara (2011), yang menyatakan bahwa produksi sawi mulai tahun 2005 sampai 2009 mengalami penurunan, yaitu 79.850 ton (2005) dan 63.911 ton (2009).

Adapun penyebab terjadinya penurunan produksi sawi sebagaimana yang dinyatakan oleh Badan Pusat Statistik Sumatera Utara diatas antara lain sebagai berikut : 1). Semakin rendahnya minat petani menanam sayuran karena dianggap tidak menguntungkan dan banyak lahan beralih fungsinya serta banyaknya sayuran impor saat ini. 2). Kondisi lahan pertanian 
yang kian hari semakin berkurang, sementara disisi lain pemenuhan kebutuhan pangan dari hasil pertanian semakin meningkat.

Jika kondisi diatas terus dibiarkan bukan tidak mungkin, 20 atau 40 tahun tidak ada lagi sayuran yang dihasilkan daerah ini. Padahal, sayuran termasuk sumber gizi yang sangat dibutuhkan masyarakat (Hendra \& Andoko 2015). Maka untuk mengatasi kendala penurunan produksi tersebut, usaha budidaya pertanian di lahan sempit. Merupakan salah satu upaya yang ditempuh adalah dengan menerapkan teknologi budidaya secara hidropoik sebagaimana yang dikemukakan (Lestari 2009). Yang mengemukakan bahwa hidroponik adalah teknologi bercocok tanam yang menggunakan air, nutrisi, dan oksigen tanpa menggunakan tanah.

Nutrisi atau unsur mineral yang dibutuhkan tanaman ada yang dalam jumlah banyak atau unsur makro, seperti nitrogen $(\mathrm{N})$, fosfor $(\mathrm{P})$, kalium $(\mathrm{K})$, kalsium $(\mathrm{Ca})$, magnesium $(\mathrm{Mg})$, dan sulfur(S). Sementara itu nutrisi yang dibutuhkan jumlah sedikit atau unusur mikro diantaranya besi $(\mathrm{Fe})$, seng $(\mathrm{Zn})$, cuprum $(\mathrm{Cu})$, dan molibdenum (Mo). (Hendra \& Andoko 2015)

Larutan pertama dari penelitian ini adalah larutan hara $\mathrm{AB}$ Mix. Budidaya sayuran daun secara hidroponik umumnya menggunakan larutan hara berupa larutan hidroponik standar ( $\mathrm{AB}$ mix). $\mathrm{AB}$ mix merupakan larutan hara yang terdiri dari larutan hara stok A yang berisi hara makro dan stok B yang berisi hara mikro. (Nugraha 2014).

Adapun beberapa media tanam sistem hidroponik antara lain sebagai berikut : (1). Arang sekam umum digunakan untuk media tanam hidroponik dibandingkan dengan sabut kelapa. Beberapa penelitian telah menyebutkan bahwa sabut kelapa mempunyai daya simpan air yang sangat baik. (Muhit \& Qodriyah 2006). (2). Rockwoll merupakan salah satu media hidroponik yang paling bayak digunakan oleh petani hidroponik khususnya di Indonesia. (Rukmana 2017). (3). Zeolit merupakan meneral yang terdiri dari kristal alumino silikat terhidrasi yang mengandung kation alkali atau alkali tanah dalam kerangka tiga demensi. (Yuanita 2009). (4). Cocopeat yaitu unsur hara makro dan mikro yang dibutuhkan tanaman diantaranya adalah kalium, fosfor, kalsium, magnesium dan natrium.. (Rukmana 2017). (5). Serbuk gergaji adalah serbuk kayu yang berasal dari kayu yang dipotong dengan gergaji. Serbuk gergaji mengandung komponen utama selulosa, hemiselulosa, lignin dan zat adektif kayu. (Rukmana 2017). (6). Penggunaan media pasir untuk budidaya tanaman secara hidroponik lebih membutuhkan pengairan dan pemupukan yang lebih intensif (Rukmana 2017).

\section{METODE PENELITIAN}

Rancangan yang digunakan adalah rancangan acak lengkap (RAL) yang disusun secara faktorial dengan menggunakan 2 faktor, yaitu perlakuan nutrisi (P) terdiri dari 3 taraf yang diteliti yaitu : $\mathrm{P} 0=$ Kontrol, $\mathrm{P} 1=$ Nutrisi AB Mix, $\mathrm{P} 2$ = Urea. Perlakuan media tanam $(\mathrm{M})$ dengan 3 taraf yang diteliti yaitu : M1 = Rockwool, M2 = Serbuk Kayu, M3 = Sekam Padi.

\section{HASIL}

\section{Parameter Tinggi Tanaman (cm)}

Menurut hasil analisis sidik ragam ANOVA dengan taraf $5 \%$ pada paramater tinggi tanaman dari umur pengamatan 1 mst, 2 mst, 3 mst dan 4 mst dengan perlakuan jenis nutrisi menunjukkan pengaruh nyata. 
Tabel 1 Interaksi kedua perlakuan terhadap parameter tinggi tanaman pada umur $1 \mathrm{mst}, 2$ mst, 3 mst dan 4 mst (cm)

\begin{tabular}{ccccc}
\hline Perlakuan & 1 MST & 2 MST & 3 MST & 4 MST \\
\hline $\mathrm{P}_{0} \mathrm{M}_{1}$ & $4.99 \mathrm{bc}$ & $11.10 \mathrm{ab}$ & $9.49 \mathrm{ab}$ & $28.34 \mathrm{a}$ \\
$\mathrm{P}_{0} \mathrm{M}_{2}$ & $4.12 \mathrm{c}$ & $9.47 \mathrm{abc}$ & $5.73 \mathrm{abc}$ & $20.32 \mathrm{ab}$ \\
$\mathrm{P}_{0} \mathrm{M}_{3}$ & $3.90 \mathrm{c}$ & $12.32 \mathrm{ab}$ & $8.78 \mathrm{ab}$ & $21.22 \mathrm{ab}$ \\
$\mathrm{P}_{1} \mathrm{M}_{1}$ & $9.97 \mathrm{a}$ & $12.91 \mathrm{ab}$ & $13.33 \mathrm{a}$ & $25.97 \mathrm{ab}$ \\
$\mathrm{P}_{1} \mathrm{M}_{2}$ & $4.93 \mathrm{bc}$ & $10.74 \mathrm{ab}$ & $6.42 \mathrm{abc}$ & $18.01 \mathrm{abc}$ \\
$\mathrm{P}_{1} \mathrm{M}_{3}$ & $5.38 \mathrm{~b}$ & $13.41 \mathrm{a}$ & $8.97 \mathrm{ab}$ & $20.12 \mathrm{ab}$ \\
$\mathrm{P}_{2} \mathrm{M}_{1}$ & $6.12 \mathrm{~b}$ & $12.53 \mathrm{ab}$ & $9.41 \mathrm{ab}$ & $28.69 \mathrm{a}$ \\
$\mathrm{P}_{2} \mathrm{M}_{2}$ & $3.48 \mathrm{c}$ & $10.26 \mathrm{ab}$ & $6.71 \mathrm{ab}$ & $18.48 \mathrm{abc}$ \\
$\mathrm{P}_{2} \mathrm{M}_{3}$ & $6.10 \mathrm{~b}$ & $12.37 \mathrm{ab}$ & $8.66 \mathrm{ab}$ & $20.70 \mathrm{ab}$ \\
\hline
\end{tabular}

Keterangan : Angka yang diikuti huruf yang sama pada kolom dan baris menunjukkan berbeda tidak nyata menurut Uji BNT $5 \%$.

Berdasarkan Tabel di atas pengaruh perlakuan jenis nutrisi dan media tanam terdapat tinggi tanaman tertinggi 1 sampai 4 mst rata- rata tertinggi terdapat pada perlakuan $\mathrm{P}_{1} \mathrm{M}_{1}(9.97,12.91,13.33$, 25.97) dan tinggi tanaman terendah terdapat pada umur 1 mst perlakuan $\mathrm{P}_{2} \mathrm{M}_{2}$ (3.48), umur 2 dan 3 mst $\mathrm{P}_{0} \mathrm{M}_{2}(9.74,5.73)$, umur 4 mst perlakuan $\mathrm{P}_{1} \mathrm{M}_{2}$ (18.01).
Jumlah Daun (Helai)

Menurut hasil analisis sidik ragam pada paramater jumlah daun sawi dengan perlakuan jenis nutrisi menunjukkan pengaruh nyata. Hasil rataan parameter jumlah daun dengan interaksi kedua perlakuan dapat pada Tabel 2.

Tabel 2 Interaksi kedua perlakuan terhadap parameter jumlah daun pada umur 1 mst, 2 mst, 3 mst dan 4 mst (cm)

\begin{tabular}{ccccc}
\hline Perlakuan & 1 MST & 2 MST & 3MST & 4 MST \\
\hline $\mathrm{P}_{0} \mathrm{M}_{1}$ & $2.56 \mathrm{abc}$ & $4.22 \mathrm{ab}$ & $5.78 \mathrm{ab}$ & $11.00 \mathrm{ab}$ \\
$\mathrm{P}_{0} \mathrm{M}_{2}$ & $3.33 \mathrm{ab}$ & $3.67 \mathrm{abc}$ & $4.78 \mathrm{ab}$ & $12.22 \mathrm{ab}$ \\
$\mathrm{P}_{0} \mathrm{M}_{3}$ & $3.44 \mathrm{ab}$ & $4.56 \mathrm{ab}$ & $6.11 \mathrm{abc}$ & $10.44 \mathrm{ab}$ \\
$\mathrm{P}_{1} \mathrm{M}_{1}$ & $5.67 \mathrm{a}$ & $5.67 \mathrm{a}$ & $7.89 \mathrm{a}$ & $12.00 \mathrm{ab}$ \\
$\mathrm{P}_{1} \mathrm{M}_{2}$ & $4.00 \mathrm{ab}$ & $4.00 \mathrm{ab}$ & $4.56 \mathrm{ab}$ & $10.33 \mathrm{abc}$ \\
$\mathrm{P}_{1} \mathrm{M}_{3}$ & $4.33 \mathrm{ab}$ & $4.56 \mathrm{ab}$ & $4.67 \mathrm{ab}$ & $10.89 \mathrm{ab}$ \\
$\mathrm{P}_{2} \mathrm{M}_{1}$ & $2.89 \mathrm{ab}$ & $4.56 \mathrm{ab}$ & $4.89 \mathrm{ab}$ & $12.11 \mathrm{ab}$ \\
$\mathrm{P}_{2} \mathrm{M}_{2}$ & $2.78 \mathrm{abc}$ & $3.56 \mathrm{abc}$ & $5.11 \mathrm{abc}$ & $8.00 \mathrm{abc}$ \\
$\mathrm{P}_{2} \mathrm{M}_{3}$ & $5.00 \mathrm{ab}$ & $4.67 \mathrm{ab}$ & $5.00 \mathrm{ab}$ & $12.33 \mathrm{a}$ \\
\hline
\end{tabular}

Keterangan : Angka yang diikuti huruf yang sama pada kolom dan baris menunjukkan tidak berbeda nyata menurut Uji BNT $5 \%$.

Berdasarkan Tabel di atas pengaruh interaksi dari perlakuan jenis nutrisi dan media tanam terdapat jumlah daun tertiggi pada umur $1 \mathrm{mst}, 2 \mathrm{mst}, 3 \mathrm{mst}$ pada perlakuan $\mathrm{P}_{1} \mathrm{M}_{1}(5.67,5.67,7.89)$ dan umur 4 mst pada pelakuan $\mathrm{P}_{2} \mathrm{M}_{3}$ (12.33). Sedangkan untuk jumlah daun terendah terdapat pada umur $1 \mathrm{mst}$ pada perlakuan $\mathrm{P}_{0} \mathrm{M}_{1}$ (2.56), umur 2 mst pada perlakuan $\mathrm{P}_{2} \mathrm{M}_{2}$ (3.56), umur 3 mst pada perlakuan
$\mathrm{P}_{1} \mathrm{M}_{2}$ (4.56), umur 4 mst pada perlakuan $\mathrm{P}_{2} \mathrm{M}_{2}$ (8.00).

\section{Luas Daun (cm)}

Menurut hasil analisis sidik ragam pada paramater luas daun dari umur pengamatan 1mst, $2 \mathrm{mst}, 3 \mathrm{mst}$ dan $4 \mathrm{mst}$ dengan perlakuan jenis nutrisi menunjukkan pengaruh nyata. Hasil rataan parameter luas daun pada umur 
pengamatan $4 \mathrm{mst}$ dengan interaksi kedua perlakuan dapat pada Tabel 3.

Tabel 3 Interaksi kedua perlakuan terhadap parameter luas daun pada umur $1 \mathrm{mst}, 2 \mathrm{mst}$, 3 mst dan 4 mst $(\mathrm{cm})$

\begin{tabular}{ccccc}
\hline Perlakuan & 1 MST & 2 MST & 3 MST & 4 MST \\
\hline $\mathrm{P}_{0} \mathrm{M}_{1}$ & $0.79 \mathrm{ab}$ & $30.61 \mathrm{ab}$ & $21.70 \mathrm{~b}$ & $177.03 \mathrm{ab}$ \\
$\mathrm{P}_{0} \mathrm{M}_{2}$ & $0.59 \mathrm{ab}$ & $22.49 \mathrm{abc}$ & $10.86 \mathrm{abc}$ & $189.45 \mathrm{ab}$ \\
$\mathrm{P}_{0} \mathrm{M}_{3}$ & $0.61 \mathrm{abc}$ & $27.09 \mathrm{ab}$ & $18.59 \mathrm{ab}$ & $185.42 \mathrm{ab}$ \\
$\mathrm{P}_{1} \mathrm{M}_{1}$ & $9.14 \mathrm{a}$ & $42.36 \mathrm{a}$ & $42.71 \mathrm{a}$ & $194.61 \mathrm{a}$ \\
$\mathrm{P}_{1} \mathrm{M}_{2}$ & $1.93 \mathrm{ab}$ & $24.62 \mathrm{ab}$ & $13.82 \mathrm{abc}$ & $136.011 \mathrm{abc}$ \\
$\mathrm{P}_{1} \mathrm{M}_{3}$ & $2.99 \mathrm{ab}$ & $35.33 \mathrm{ab}$ & $18.93 \mathrm{ab}$ & $174.23 \mathrm{ab}$ \\
$\mathrm{P}_{2} \mathrm{M}_{1}$ & $2.14 \mathrm{ab}$ & $38.07 \mathrm{ab}$ & $21.79 \mathrm{~b}$ & $190.41 \mathrm{ab}$ \\
$\mathrm{P}_{2} \mathrm{M}_{2}$ & $0.88 \mathrm{abc}$ & $21.76 \mathrm{abc}$ & $13.92 \mathrm{abc}$ & $99.16 \mathrm{abc}$ \\
$\mathrm{P}_{2} \mathrm{M}_{3}$ & $3.40 \mathrm{ab}$ & $34.01 \mathrm{ab}$ & $18.80 \mathrm{ab}$ & $168.45 \mathrm{ab}$ \\
\hline
\end{tabular}

Keterangan : Angka yang diikuti huruf yang sama pada kolom dan baris menunjukkan tidak berbeda nyata menurut Uji BNT $5 \%$.

Berdasarkan Tabel di atas untuk perlakuan jenis nutrisi terdapat luas daun tertinggi 1 sampai 4 minggu setelah tanam rata- rata tertinggi terdapat pada perlakuan $\mathrm{P}_{1} \mathrm{M}_{1} \quad$ (9.14, 42.36, 42.71, 194.61). Sedangkan umur 1 mst pada perlakuan
$\mathrm{P}_{0} \mathrm{M}_{2}$ (0.59), umur 2 mst pada perlakuan $\mathrm{P}_{2} \mathrm{M}_{2}$ (21.76), umur 3 mst pada perlakuan $\mathrm{P}_{0} \mathrm{M}_{2}$ (10.86) dan pada umur 4 mst pada perlakuan $\mathrm{P}_{2} \mathrm{M}_{2}$ (99.16) menunjukkan luas daun terendah.

\section{Warna Daun}

Tabel 4 Parameter warna daun pada umur 1 mst, 2 mst, 3 mst, 4 mst

\begin{tabular}{cccc}
\hline $\begin{array}{c}\text { Perlakuan Jenis } \\
\text { Nutrisi } \\
\mathbf{1} \text { Mst }\end{array}$ & \multicolumn{3}{c}{ Perlakuan Media Tanam } \\
\cline { 2 - 4 } & $\mathbf{M}_{\mathbf{1}}$ & $\mathbf{M}_{\mathbf{2}}$ & $\mathbf{M}_{\mathbf{3}}$ \\
\hline $\mathrm{P}_{0}$ & Hijau & Hijau & Hijau \\
$\mathrm{P}_{1}$ & Hijau & Hijau & Hijau \\
$\mathrm{P}_{2}$ & Hijau & Hijau & Hijau \\
\hline $\mathbf{2}$ mst & $\mathbf{M}_{\mathbf{1}}$ & $\mathbf{M}_{\mathbf{2}}$ & $\mathbf{M}_{\mathbf{3}}$ \\
\hline $\mathrm{P}_{0}$ & Hijau & Hijau & Kekuningan \\
$\mathrm{P}_{1}$ & Hijau Gelap & Hijau Gelap & Hijau Gelap \\
$\mathrm{P}_{2}$ & Hijau Gelap & Hijau Muda & Kekuningan \\
\hline $\mathbf{3}$ mst & $\mathbf{M}_{\mathbf{1}}$ & $\mathbf{M}_{\mathbf{2}}$ & M \\
\hline $\mathrm{P}_{0}$ & Hijau & Kekuningan & Kekuningan \\
$\mathrm{P}_{1}$ & Hijau Gelap & Hijau Muda & Hijau Muda \\
$\mathrm{P}_{2}$ & Hijau & Hijau Gelap & Hijau Muda \\
\hline $\mathbf{4}$ mst & M & M & M \\
\hline $\mathrm{P}_{0}$ & Hijau & Kekuningan & Kekuningan
\end{tabular}




\begin{tabular}{cccc}
$\mathrm{P}_{1}$ & Hijau Gelap & Hijau & Hijau \\
$\mathrm{P}_{2}$ & Hijau & Hijau Gelap & Hijau \\
\hline
\end{tabular}

Berdasarkan Tabel di atas untuk perlakuan jenis nutrisi terdapat warna daun terbaik 1 sampai 4 minggu setelah tanam setelah dilihat dengan uji ANOVA dengan taraf 5\% terdapat warna yang baik pada perlakuan $\mathrm{P}_{1}$ (Hijau Gelap) dan kurang baik terdapat pada perlakuan $\mathrm{P}_{0}$ (Kekuningan). Sedangkan untuk perlakuan media tanam terdapat warna daun terbaik pada perlakuan $\mathrm{M}_{1}$ (Hijau Gelap) dan warna daun kurang nutrisi terdapat pada perlakuan $\mathrm{M}_{2}$ (Kekuningan), sedangkan interaksi dari kedua perlakuan terdapat warna daun terbaik 1 sampai 4 minggu setelah tanam pada perlakuan $\mathrm{P}_{1} \mathrm{M}_{1}$ (Hijau
Gelap) kemudian untuk warna daun kurang baik terdapat pada perlakuan $\mathrm{P}_{0} \mathrm{M}_{2}$ (Kekuningan).

\section{Berat Sawi Per Sampel (gr)}

Menurut hasil analisis sidik ragam pada parameter berat sawi per sampel dengan interaksi kedua perlakuan menunjukkan pengaruh sangat nyata. Daftar sidik ragam pada pengamatan paramater berat sawi per sampel dengan perlakuan jenis nutrisi dan media tanam. Hasil rataan parameter berat sawi per sampel dengan interaksi kedua perlakuan dapat pada Tabel 5.

Tabel 5 Interaksi kedua perlakuan terhadap parameter berat sawi per sampel (gr)

\begin{tabular}{cc}
\hline Perlakuan & Rataan \\
\hline $\mathrm{P}_{0} \mathrm{M}_{1}$ & $47.78 \mathrm{ab}$ \\
$\mathrm{P}_{0} \mathrm{M}_{2}$ & $32.22 \mathrm{abc}$ \\
$\mathrm{P}_{0} \mathrm{M}_{3}$ & $30.00 \mathrm{abc}$ \\
$\mathrm{P}_{1} \mathrm{M}_{1}$ & $81.11 \mathrm{a}$ \\
$\mathrm{P}_{1} \mathrm{M}_{2}$ & $44.44 \mathrm{ab}$ \\
$\mathrm{P}_{1} \mathrm{M}_{3}$ & $54.44 \mathrm{ab}$ \\
$\mathrm{P}_{2} \mathrm{M}_{1}$ & $77.78 \mathrm{ab}$ \\
$\mathrm{P}_{2} \mathrm{M}_{2}$ & $46.67 \mathrm{ab}$ \\
$\mathrm{P}_{2} \mathrm{M}_{3}$ & $56.67 \mathrm{ab}$ \\
\hline
\end{tabular}

Keterangan : Angka yang diikuti huruf yang sama pada kolom dan baris menunjukkan tidak berbeda nyata menurut Uji BNT $5 \%$.

Berdasarkan Tabel di atas pengaruh interaksi dari kedua perlakuan terdapat berat sawi per sampel tertinggi pada perlakuan $\mathrm{P}_{1} \mathrm{M}_{1}$ (81.11) dan berat sawi per sampel terendah terdapat pada perlakuan $\mathrm{P}_{0} \mathrm{M}_{3}$ (30.00).

\begin{abstract}
Berat Sawi Per Plot (gr)
Menurut hasil analisis sidik ragam pada paramater berat sawi per plot dengan perlakuan jenis nutrisi menunjukkan pengaruh nyata. Hasil rataan parameter berat sawi per plot dengan interaksi kedua perlakuan dapat pada Tabel 6.
\end{abstract}

Tabel 6 Interaksi kedua perlakuan terhadap parameter berat sawi per plot (gr)

\begin{tabular}{cc}
\hline Perlakuan & Rataan \\
\hline $\mathrm{P}_{0} \mathrm{M}_{1}$ & $143.33 \mathrm{ab}$ \\
$\mathrm{P}_{0} \mathrm{M}_{2}$ & $90.00 \mathrm{abc}$ \\
$\mathrm{P}_{0} \mathrm{M}_{3}$ & $96.67 \mathrm{abc}$ \\
$\mathrm{P}_{1} \mathrm{M}_{1}$ & $246.67 \mathrm{a}$ \\
$\mathrm{P}_{1} \mathrm{M}_{2}$ & $133.33 \mathrm{ab}$ \\
$\mathrm{P}_{1} \mathrm{M}_{3}$ & $160.00 \mathrm{ab}$
\end{tabular}




$\begin{array}{cc}\mathrm{P}_{2} \mathrm{M}_{1} & 223.33 \mathrm{ab} \\ \mathrm{P}_{2} \mathrm{M}_{2} & 140.00 \mathrm{ab} \\ \mathrm{P}_{2} \mathrm{M}_{3} & 170.00 \mathrm{ab}\end{array}$

Keterangan : Angka yang diikuti huruf yang sama pada kolom dan baris menunjukkan tidak berbeda nyata menurut Uji BNT $5 \%$.

Berdasarkan Tabel di atas interaksi dari kedua perlakuan terdapat tinggi berat sawi per plot tertinggi pada perlakuan $\mathrm{P}_{1} \mathrm{M}_{1}$ (246.67) dan berat sawi per plot terendah terdapat pada perlakuan $\mathrm{P}_{0} \mathrm{M}_{2}$ (90.00).

\section{PEMBAHASAN}

Menurut hasil analisis ragam pada paramater tinggi tanaman dari umur pengamatan $1 \mathrm{mst}, 2 \mathrm{mst} 3 \mathrm{mst}$, dan $4 \mathrm{mst}$ dengan interaksi kedua perlakuan menunjukkan pengaruh sangat siknifikan. Pengaruh interaksi antara perlakuan media tanam dan jenis nutrisi terhadap pertumbuhan tanaman sangat siknifikan terhadap tinggi tanaman disebabkan oleh perlakuan $\mathrm{P}_{1} \mathrm{M}_{1}$ ( $\mathrm{AB}$ Mix dan rockwool) sebesar $25.97 \mathrm{~cm}$, sedangkan tinggi tanaman terndah pada perlakuan $\mathrm{P}_{1} \mathrm{M}_{2}(\mathrm{AB}$ Mix dan serbuk kayu), yang dilakukan dalam penelitian ini saling mendukung terhadap pertumbuhan parameter tinggi tanaman.

Jumlah daun pada umur $1 \mathrm{mst}, 2 \mathrm{mst}$, 3 mst dan 4 mst dengan interaksi kedua perlakuan menunjukkan pengaruh sangat siknifikan. Jumlah daun terbanyak terdapat pada kombinasi perlakuan $\mathrm{P}_{2} \mathrm{M}_{3}$ (pupuk Urea dan sekam padi) sebesar 12.33 helai dan tanaman terendah terdapat pada kombinasi perlakuan $\mathrm{P}_{2} \mathrm{M}_{2}$ (pupuk Urea dan sekam padi) sebesar 8.00 helai. Jumlah daun dipengaruhi oleh ketersediaan air, nutrisi dan cahaya matahari untuk melakukan proses fotosintesis. Dari kombinasi perlakuan tersebut yang paling berpengaruh terhadap jumlah daun adalah kombinasi pupuk $\mathrm{AB}$ Mix dan rockwool sedangkan kombinasi perlakuan yang tidak berpengaruh terhadap jumlah daun adalah kombinasi pupuk Urea dan serbuk kayu.
Menurut hasil analisis sidik ragam pada paramater luas daun dari umur pengamatan $1 \mathrm{mst}, 2 \mathrm{mst} 3 \mathrm{mst}$, dan $4 \mathrm{mst}$ dengan interaksi kedua perlakuan menunjukkan pengaruh sangat siknifikan. Pengaruh interaksi antara perlakuan media tanam dan jenis nutrisi terhadap pertumbuhan tanaman sangat siknifikan terhadap luas daun disebabkan oleh perlakuan $\mathrm{P}_{0} \mathrm{M}_{3}$ (kontrol dan sekam padi) sebesar $194.61 \mathrm{~cm}$, sedangkan luas daun terendah pada perlakuan $\mathrm{P}_{2} \mathrm{M}_{2}$ (pupuk Urea dan serbuk kayu). Hal ini didukung oleh Siswadi \& Teguh (2013) yang menyatakan pertumbuhan akar mampu menyerap nutrisi yang tersedia terutama unsur $\mathrm{N}$ yang sangat berperan dalam pembentukan daun sehingga daun tumbuh lebih lebar dan menyebabkan luas daun yang lebih besar. (Siswadi \& Teguh 2013)

Hasil dari data secara fisual warna daun tanaman yang terbaik $\mathrm{P}_{1} \mathrm{M}_{1}$ (AB Mix dan rockwool) dan $\mathrm{P}_{1} \mathrm{M}_{3}$ (AB MIX dan sekam padi), sedangkan warna daun yang kurang baik ditunjukkan pada perlakuan $\mathrm{P}_{0} \mathrm{M}_{2} \quad$ (kontrol dan serbuk kayu) berdasarkan parameter warna daun. Apabila unsur tersebut tidak tersedia bagi tanaman, maka tanaman akan menunjukkan gejala kekurangan unsur tersebut dan pertumbuhan tanaman akan merana. Berdasarkan jumlah yang diperlukan kita mengenal adanya unsur hara makro dan unsur hara mikro. Dari hasil penelitian bahwa tinggi tanaman, jumlah daun, lebar daun, warna daun dan hasil produksi tanaman sawi tidak terlepas dari kombinasi perlakuan antara media tanam dan larutan nutrisi yang diberikan. Hal ini membuktikan bahwa tanaman selain membutuhkan media tanam untuk menopang berdiri dan larutan nutrisi yang sesuai untuk pertumbuhan tanaman hingga berproduksi juga membutuhkan sinar 
matahari yang cukup untuk proses fotosintesis pada tanaman.

\section{KESIMPULAN}

Jenis nutrisi yang paling berpengaruh terhadap pertumbuhan tanaman sawi (Brassica juncea $\mathrm{L}$ ) ialah $\mathrm{P}_{1}$ ( pupuk $\mathrm{AB}$ Mix). Media tanam yang berpengaruh dalam penelitian tanaman sawi dengan sistem apung adalah : Media tanam yang berpengaruh untuk tinggi tanaman, luas daun dan warna daun, jumlah daun, berat per sampel dan berat per plot dan ialah $\mathrm{M}_{1}$ (rockwool). Media tanam yang tidak pengaruh ialah $\mathrm{M}_{2}$ (serbuk kayu) berdasarkan analisis sidik ragam yang menunjukkan pertumbuhan yang lambat dan produksi yang sedikit dibandingkan dengan media yang lain. Jenis nutrisi dan media tanam yang berpengaruh terhadap tinggi tanaman, luas daun dan warna daun, jumlah daun, berat per sampel dan berat per plot ialah $\mathrm{P}_{1} \mathrm{M}_{1}$ (pupuk $\mathrm{AB}$ Mix dan media tanam rockwool).

\section{SARAN}

Untuk meningkatkan keberhasilan system hidroponik seperti yang sudah dilakukan maka peneliti menyarankan dalam penggunaan media tanam serbuk kayu, seharusnya dicuci terlebih dahulu karna mengandung zat toksik atau zat tannin yang dapat menghambat pertumbuhan. Agar menyediakan bahanbahan seperti pipa pvc dengan ukuran lubang yang tepat agar saat diterpa angin wadah tempat penelitian (botol mineral) tidak renggang.

\section{DAFTAR PUSTAKA}

Badan Pusat Statistik Sumatera Utara. 2011. Produksi Sawi Sumatera Utara. Jakarta (ID): Badan Pusat Statistik Republik Indonesia.

Hendra A, Andoko A. 2015. Bertanam Sayuran Hidroponik Ala Pak Tani Hydrofoam. Jakarta (ID): PT Agromedia Pustaka

Lestari G. 2009. Berkebun Sayuran Hidroponik di Rumah. Jakarta (ID): Prima InfoSarana

Muhit A, Qodriyah L.2006. Respon beberapa kultivar Mawar (Rosa hybridal) pada media hidroponik terhadap pertumbuhan dan produksi bunga. Buletin Teknik Pertanian. 11: 29-32.

Nugraha RU. 2014. sumber hara sebagai pengganti $\mathrm{AB}$ mix pada budidaya sayuran daun secara hidroponik. [skripsi]. Bogor (ID): Institut Pertanian Bogor.

Rukmana R. 2007. Bertanam Petsay dan Sawi. Yogyakarta (ID): Kanisius.

Siswadi, Teguh Y. 2013. Uji hasil tanaman sawi pada berbagai media tanam secara hidroponik. Jurnal Innofarm. 2 (1): 44-50. 